\title{
Circulating tumor cells and miRNAs as prognostic markers in neuroendocrine neoplasms
}

\author{
Maria Chiara Zatelli1, Erika Maria Grossrubatscher2, Elia Guadagno3, \\ Concetta Sciammarella4, Antongiulio Faggiano 5 and Annamaria Colao 4 \\ ${ }^{1}$ Department of Medical Sciences, Section of Endocrinology and Internal Medicine, University of \\ Ferrara, Ferrara, Italy \\ 2Endocrine Unit, ASST Grande Ospedale Metropolitano Niguarda, Milano, Italy \\ ${ }^{3}$ Department of Advanced Biomedical Sciences, Pathology Section, University of Naples Federico II, \\ Naples, Italy \\ ${ }^{4}$ IOS \& COLEMAN Srl, Naples, Italy \\ 5Thyroid and Parathyroid Surgery Unit, Istituto Nazionale per lo Studio e la Cura Dei Tumori \\ 'Fondazione G. Pascale' - IRCCS, Naples, Italy
}

Correspondence

should be addressed

to M C Zatelli

Email

ztImch@unife.it

\begin{abstract}
The prognosis of neuroendocrine neoplasms (NENs) is widely variable and has been shown to associate with several tissue- and blood-based biomarkers in different settings. The identification of prognostic factors predicting NEN outcome is of paramount importance to select the best clinical management for these patients. Prognostic markers have been intensively investigated, also taking advantage of the most modern techniques, in the perspective of personalized medicine and appropriate resource utilization. This review summarizes the available data on the possible role of circulating tumor cells and microRNAs as prognostic markers in NENs.
\end{abstract}
Key Words
- neuroendocrine tumors
- circulating biomarkers
- prognosis
- miRna
$\rightarrow$ CTC

\section{Introduction}

Neuroendocrine neoplasms (NENs) are heterogeneous tumors with widely different behavior and prognosis, that to date had been related mainly to the grade of neuroendocrine differentiation as well as the proliferative attitude of these tumors, measured by means of the Ki67 labeling index. However, as underlined by the ENETS guidelines, NEN prognosis may also depend on patient age, tumor site, metastatic spread and hormonal production. Several methods have been proposed to predict overall survival (OS) and progression-free survival (PFS) of NEN patients, including clinical nomograms taking into account the number of liver metastases, tumor size and Ki67 index (Ruzzenente et al. 2016) or blood neutrophilto-lymphocyte ratio, Ki67 index and lymph node ratio (Cao et al. 2016), positron emission tomography results by means of new tracers, such as (18)F-fluorothymidine (Johnbeck et al. 2016), or molecular markers, such as HOPX promoter methylation/gene expression (Ushiku et al. 2016) or phosphorylated histone H3 assessment (Villani et al. 2016). Besides tissue-based characteristics, blood-based biomarkers have been considered, also due to easy accessibility of the compartment and possibility 
of multiple sampling. Among circulating biomarkers, chromogranin A has been measured in several NEN settings, but its value as a prognostic biomarker in NEN patients is limited (Capdevila et al. 2014), similar to other monoanalyte biomarkers (Oberg et al. 2015, Verbeek et al . 2016). The identification of prognostic factors capable of predicting the outcome of NENs is crucial in order to plan an adequate clinical management. Therefore, other attempts have been made, also on the basis of the results of studies performed in cancer fields different from NENs.

\section{Aim}

The aim of this review is to summarize the available data on two new putative prognostic biomarkers for NENs, such as circulating tumors cells (CTCs) and microRNAs (miRNAs).

\section{Methods}

Among the six authors, four (MCZ, EMG, EG and CS) independently searched MEDLINE (PubMed database) to detect articles published in the English language reporting on the prognostic value of CTCs and miRNAs in NENs, excluding Editorials and Letters. The search was last updated February 23, 2017. Additional studies were identified by reviewing the references of all selected articles. Three authors (MCZ, EG and CS) managed articles dealing with CTCs and four authors (MCZ, EMG, EG and CS) managed articles dealing with miRNA.

\section{Part 1. Circulating tumor cells}

Biogenesis and detection of circulating tumor cells Circulating tumor cells (CTCs) are released into the circulatory system from primary or metastatic tumors, depending on the disease stage. The biogenesis of CTCs can be summarized in three steps: intravasation, migration and extravasation (Chen \& Bai 2015). During the first step, tumor cells may transform to mesenchymal-like cells and intrude the blood vessel wall, entering the blood stream (Thiery 2002). Then, tumor cells migrate as single elements or in cellular clusters (microemboli). Finally, after reaching appropriate distant sites of the body, cells exit blood vessels and seed new tumor lesions (Chen \& Bai 2015). The population of CTCs includes both epithelial and mesenchymal-like cells, non-stem and stem-like cells. Most of CTCs departing the primary tumor will die, whereas about $0.01 \%$ of CTCs are likely to form metastases, as observed in preclinical models (Fidler 1970, Langley \& Fidler 2011).

CTC detection consists of two main steps: enrichment and identification procedures. Enrichment techniques are based on cellular physical (size/deformability, density and electric charge) or biological properties (expression of specific antigens on the surface of neoplastic cells) (Alix-Panabieres \& Pantel 2013). Most of the studies concerning the prognostic role of CTCs in cancer have been performed by using the Cell Search system (Veridex), which is the only currently FDA-approved system for the detection of CTCs in patients with metastatic breast, prostate and colorectal cancers (Cristofanilli et al. 2004, Danila et al. 2007, Cohen et al. 2008, de Bono et al. 2008, Olmos et al. 2009). Cell Search is a semi-automated system of CTCs detection from a small volume of blood sample $(7.5 \mathrm{~mL})$, based on immunomagnetic assays that target the antigens through magnetically bound antibodies and allows cell capture after exposure to a magnetic field. A positive selection of cells with the ferrofluid-bound antibody against epithelial cell adhesion molecule-1 (EpCAM) is carried out. After enrichment, a substantial number of leucocytes is still to be depleted. Subsequently, a strategy for CTC identification is performed: enriched cells are permeabilized, fixed and labeled with the fluorescent nuclear dye DAPI and fluorescent antibodies directed against the leukocyte antigen CD45 and the epithelial markers cytokeratins (CK) 8, 18 and 19. A semiautomated fluorescence microscope scans the sample and produces images that are then selected by trained operators. CTCs are DAPI+ (contain a nucleus), CK+ (express epithelial markers) and CD45- (negative for leucocyte common antigen). Analysis of neuroendocrine CTCs has been performed by using fluorescent antibodies against synaptophysin and CD56 (Khan et al. 2011), but they are not routinely used. Cell Search equipment can be used by applying protocols for molecular profiling, flow cytometry and FISH techniques (Sieuwerts et al. 2009). Enrichment methods based on physical properties include density gradient centrifugation, filtration, labelfree biochips or dielectrophoresis (Parkinson et al. 2012); those based on biological properties are antibody-based magnetic or antibody-based microfluidic platforms (AlixPanabieres \& Pantel 2013). The functional EPISPOT assay can be added to the enrichment step, in order to identify only vital cells by measuring secreted, shed and released proteins in $24-48 \mathrm{~h}$ of short-term culture (Alix-Panabieres 2012). Cell Search system received regulatory approval for routine clinical use due to the high reproducibility and 
purity yields (Wang et al. 2016). For all other systems, limited data are available concerning their clinical applications; therefore, results still must be validated in large clinical studies. At the same time, Cell Search system has an inherent limitation that hampers the detection of EpCAM-negative CTCs. This drawback is overcome by a negative enrichment method (CD45-) combined with immunostaining-fluorescence ISH, which is able to yield CTCs independently of EpCAM expression and cell size (Gao et al. 2016). A possible limitation, in case of earlystage cancer, is the difficulty to count CTCs as they are expected to be few, corresponding to a low sensitivity of the method. A possible efficient strategy to overcome this problem is to directly target the cells in vivo. GILUPI GmbH approach is based on the application of an antibodycoated wire into a peripheral arm vein for a duration of $30 \mathrm{~min}$ (Saucedo-Zeni et al. 2012). After removing the wire, isolated CTCs can be removed for immunocytochemical and molecular analysis. This innovative method needs to be validated in order to establish its clinical relevance.

Other detection methods are Epic sciences and Maintrac. Epic sciences (Bethel et al. 2014) separates nucleated cells from red blood cells and the former are exposed to four fluorescent markers. Each cell is then analyzed for 90 parameters including the fluorescence intensity of the 4 markers and other 86 different morphologic parameters; an image analysis system identifies each cell with specific coordinates and a hematopathology-trained algorithm proposes candidate CTCs that are confirmed by a trained reader. Maintrac (Pachmann et al. 2008) applies an approach based on microscopic identification of CTCs: it does not purify or enrich them, but it identifies them among other blood compounds by the use of a fluorescent marker (EPCAM). Only vital cells are counted by this system, and the nuclear staining with propidium iodide is used to distinguish vital from dead cells. With this method, the prognostic marker is represented by the cell count dynamics and not by the single cell count. Other techniques used to detect CTCs are available (Fabisiewicz \& Grzybowska 2017), but they lack the robust validation and reproducibility of Cell Search, and their description is beyond the scope of the present review.

Circulating tumor cells as prognostic markers in human cancers The role of CTCs in cancer has been extensively investigated, especially in breast cancer. The American Society of Clinical Oncology guidelines (Harris et al. 2007) did not recommend the use of CTC measurement for diagnosis nor for treatment modifications in breast cancer. However, there is solid evidence showing its value as stable prognosticator both in early stage and metastatic disease. Indeed, a meta-analysis (Zhang et al. 2012) conducted on 49 relevant publications pointed out that $>1 \mathrm{CTC} / 7.5 \mathrm{~mL}$ represents a significant risk factor for both PFS in case of metastatic disease, diseasefree survival (DFS) in case of early-stage disease and OS. A $5 / 7.5 \mathrm{~mL}$ cut-off has been cleared by the FDA only for metastatic breast disease. In order to predict tumor response to drugs, an assay based on both measurement and evaluation of protein expression (Hormone receptor, Her2) in CTCs has been developed (Mathew et al. 2015). On the basis of a well-recognized prognostic role for CTCs in breast cancer, many 'interventional' trials have been designed in metastatic disease settings (Bidard et al. 2013, Smerage et al. 2014). Similarly, CTCs have been approved by the FDA as a valid prognostic factor in progressive prostate cancer (Danila et al. 2007), where morbidity is mainly related to disease progression despite hormonal treatment (castration-resistant prostate cancer (CRPC)). CRPC patients can be categorized prospectively as having either unfavorable (baseline CTC level count $>5 / 7.5 \mathrm{~mL}$ ) or favorable outcome (baseline CTC count $<5 \mathrm{CTC} / 7.5 \mathrm{~mL}$ ). It has also been demonstrated that post-treatment CTC count can be predictive of survival (de Bono et al. 2008). Also in the settings of metastatic colorectal cancer (mCRC), CTCs have been recognized by the FDA (Cohen et al. 2008) as having an independent prognostic value. Therefore, CTCs may represent a prognostic marker in several cancer patients and may be useful to guide treatment approaches and evaluate patients response (Wang et al. 2017).

\section{Circulating tumor cells as prognostic markers} in neuroendocrine tumors $O n$ the basis of the evidence that CTCs have a prognostic role in several human cancers, this aspect has been investigated also in the field of NENs. The first study addressing this issue was published in 2011 (Khan et al. 2011), investigating the feasibility of CTC detection in patients with metastatic NENs and its potential prognostic role. The authors were capable of demonstrating strong EpCAM protein expression in formalin-fixed, paraffinembedded (FFPE) gastroenteropancreatic (GEP) NEN tissues by immunohistochemistry and therefore set out to assess CTCs in 79 patients with metastatic NENs by using the Cell Search system. They found a variable number of CTCs in nearly 1 out of 2 patients with midgut NENs and 1 out of 5 patients with pancreatic 
NENs (pNENs). Stable disease strongly associated with the absence of CTCs, whose levels correlated with urinary 5-hydroxyindole acetic acid levels and liver metastases extension, providing the first evidence that CTCs may be considered as a prognostic marker also in NENs. However, the patients were highly heterogeneous and therefore the authors performed a second study on 175 patients with metastatic NENs (Khan et al. 2013), that confirmed the feasibility of CTC count in these settings. In addition, the study showed that patients with more than one CTC displayed worse PFS and OS as compared to patients with $<1$ CTC, independently of other prognostic markers. To clarify whether CTCs may also predict the response to treatment, the same authors (Khan et al. 2016) evaluated CTC count before and after treatment in 138 metastatic NEN patients (31 pNEN including 9 G1, 7 G2 and 15 G3; 81 midgut NENs including 48 G1, 28 G2 and 5 G3; 12 lung NENs including 4 G1, 6 G2 and 3 G3) and found that first post-treatment CTC count was significantly associated with progressive disease. Indeed, a better outcome was recorded in patients that did not have CTCs before and after therapy and in patients displaying a $>50 \%$ reduction in CTC count after treatment. The prognostic value of CTC count was confirmed by the evidence that CTCs strongly correlated with OS also in multivariate analysis, indicating that CTC count, independently of tumor grade, may be a useful tool to help guiding therapeutic decisions. However, this study groups different types of NENs, that have very different clinical behavior and follow-up schedules that may hamper the clinical applicability of this method. This limitation is being dealt with in a phase IV, multicenter, open-label, single-group exploratory study that is now ongoing in order to evaluate whether monitoring CTCs count can predict clinical symptomatic response, as well as quality of life and PFS, in patients with functioning midgut NENs treated with a somatostatin analogue (circulating tumor cells in Somatuline Autogel-treated neuroendocrine tumors patients (CALM-NET); ClinicalTrials.gov Identifier: NCT02075606). In addition, the employed dynamic approach overcomes the limit of applying a single CTC threshold level, as in previous studies performed in the settings of epithelial tumors (Cristofanilli et al. 2004, de Bono et al. 2008, Cohen et al. 2009) as it analyzes the percent CTC changes following treatment.

Concerning specific NEN histotypes, the utility of CTC count has been explored in patients with Merkel cell carcinoma (MCC) in two different studies employing the Cell Search system (Blom et al. 2014,
Gaiser et al. 2015). Their findings support the prognostic role for CTCs also in MCC, since Blom and coworkers (Blom et al. 2014) showed that patients with a negative CTC count display a better prognosis. However, the difference in the time of blood withdrawal with respect to disease stage and treatment limits the value of these findings. Gaiser and coworkers (Gaiser et al. 2015) evaluated CTCs in 30 patients with MCC confirming that these patients display a high CTC count. However, the study has important technical limitations as the heterogeneity of the patient sample prevented the identification of a correlation between tumor stage and CTC and the employed method detected CTCs also in control subjects, indicating a low specificity. On the other hand, they found significantly higher CTC counts in patients with active disease as compared to controls, supporting the need for further studies to improve the prognostic significance of CTCs in the follow-up of MCC patients. CTCs have also been investigated as prognostic markers in small-cell lung cancer (SCLC) by Hiltermann and coworkers (Hiltermann et al. 2012) who found that CTC count, assessed by the Cell Search system, correlated with tumor bulk and confirmed that the absence of CTCs at diagnosis associates with prolonged survival. Although in these settings CTC count did not predict response to chemotherapy, it represented the strongest predictor of OS after the first cycle of chemotherapy. Along this line, a recent research highlighted that copy number aberrations (CNAs) in CTCs of SCLC patients could correctly identify patients as chemorefractory or chemosensitive, indicating that CTC CNA may represent a further predictive and prognostic marker in these settings (Carter et al. 2017). Similarly, in EGFR-mutant patients with non-small-cell lung cancer (NSCLC), prospective trials employing the Cell Search system showed that CTCs are valuable and non-invasive tools to evaluate acquired resistance to chemotherapy treatment (Yanagita et al. 2016). In addition, a cut-off value of $>5$ CTC/7.5 mL of blood using Cell Search has been shown to be highly significant in predicting worse prognosis in NSCLC patients (Krebs et al. 2011). The most relevant findings are summarized in Table 1.

There are still more questions than answers concerning optimal technologies for CTC detection, analysis, biological significance and clinical utility. However, they may represent an important tile in the future development of 'liquid biopsies' as they mark the presence of a tumor and/or its metastases, as recently underlined (Dive \& Brady 2017). 
Table 1 Prognostic role of CTCs in NENs.

\begin{tabular}{|c|c|c|}
\hline Series & Findings & Reference \\
\hline $\begin{array}{l}79 \text { metastatic NENs: } \\
\text { - } 19 \text { pancreatic } \\
-42 \text { midgut } \\
-13 \text { bronchopulmonary } \\
-5 \text { unknown primary }\end{array}$ & $\begin{array}{l}\text { - Moderate correlation }(r=0.5, P=0.007) \text { between CTCs count and urinary } \\
\text { 5-HIAA in midgut and unknown primary NENs } \\
\text { - Significant association between CTCs count and tumor burden of liver } \\
\text { metastase }(B=8.91,95 \% \mathrm{Cl}=4.3-13.5, P<0.001) \\
\text { - No correlation between CTCs count and Ki67 }(r=0.08, P=0.59) \text { and low } \\
\text { correlation between CTCs count and serum CgA }(r=0.246, P=0.03) \\
\text { - } 0 \text { CTCs associated with stable disease }(P<0.001)\end{array}$ & Khan et al. (2011) \\
\hline $\begin{array}{l}175 \text { metastatic NENs: } \\
-42 \text { pancreatic } \\
-101 \text { midgut } \\
-17 \text { bronchopulmonary } \\
-12 \text { unknown primary } \\
-3 \text { hindgut }\end{array}$ & $\begin{array}{l}\text { - Significant association between CTCs count }(\geq 1) \text { and grade }(P=0.036) \text {, } \\
\text { tumor burden }>25 \%(P<0.001) \text { and serum chromogranin } A>120 \text { pmol/L } \\
(P<0.001) \text {, respectively } \\
\text { - CTCs count } \geq 1 \text { related with worse PFS (HRs: } 6.6, P<0.001) \text { and OS (HRs: } \\
8.0, P<0.001) \\
\text { Within grade } 1 \text {, two CTCs-based subgroups: HRs }=5.0 \text { for PFS }(P=0.017) \\
\text { and HRs }=7.2 \text { for OS }(P=0.023) \\
\text { Within grade } 2 \text {, two CTCs-based subgroups: HRs }=3.5 \text { for PFS }(P=0.018) \\
\text { and HRs }=5.2 \text { for OS }(P=0.036)\end{array}$ & Khan et al. (2013) \\
\hline $\begin{array}{l}138 \text { metastatic NENs: } \\
-31 \text { pancreatic } \\
-81 \text { midgut } \\
-12 \text { bronchopulmonary } \\
-11 \text { unknown primary } \\
-3 \text { hindgut }\end{array}$ & $\begin{array}{l}\text { - Significant association }(P<0.001) \text { between the first post-treatment (after } \\
3-5 \text { weeks) CTCs count and progressive disease }(\mathrm{PD}) \text { : PD in } 8 \% \text { of patients } \\
\text { with 'favorable count' ( } 0 \text { CTCs at baseline and after treatment, or } \geq 50 \% \\
\text { CTCs reduction after treatment) vs } 60 \% \text { in unfavorable group }(<50 \% \mathrm{CTCs} \\
\text { reduction or increase) } \\
\text { - Changes in CTCs count at the first post-treatment time (after } 3-5 \text { weeks) } \\
\text { strongly associated with OS }(P<0.001) \text { : the best outcome in group with } 0 \\
\text { CTCs count at baseline, followed by the group with } \geq 50 \% \text { CTCs reduction } \\
\text { after treatment (HRs }=3.31 ; 95 \% \mathrm{Cl}=1.50-7.32) \text { and then the group with } \\
<50 \% \text { CTCs reduction or increase (HRs }=5.07 ; 95 \% \mathrm{Cl}=2.48-10.38) \\
\text { - In multivariate analysis changes from baseline CTCs count }(P=0.0002) \text { and } \\
\text { grade }(P=0.0046) \text { resulted independent prognostic factors }\end{array}$ & Khan et al. (2016) \\
\hline 34 Merkel cell carcinomas & $\begin{array}{l}\text { - Correlation between CTCs positivity }(\geq 1 \text { CTCS) and extent of disease } \\
(P=0.004) \\
\text { - Statistically significant difference in median OS between CTCs positive } \\
\text { and CTCs negative samples }(P=0.0003) \text {, also in case of regional node } \\
\text { metastases }(P=0.015)\end{array}$ & Blom et al. (2014) \\
\hline 30 Merkel cell carcinomas & $\begin{array}{l}\text { - Significantly higher CTCs count in patients with active disease } \\
\text { - Increasing CTCs count associated with development of new metastases }\end{array}$ & Gaiser et al. (2015) \\
\hline 59 Small cell lung cancers & $\begin{array}{l}\text { - Association between CTCs count }<2 \text { and prolonged OS and PFS }(P \leq 0.001) \\
\text { - CTCs count decrease after the first cycle of therapy correlated with longer } \\
\text { OS and PFS }(P \leq 0.001) \\
\text { - CTCs count decrease after four cycles of therapy correlated with longer } \\
\text { OS }(P=0.05) \text { and PFS }(P=0.007) \\
\text { - CTCs count }<2 \text { after the first cycle of therapy is an independent } \\
\text { prognostic factor for OS in multivariate analysis (HRs }=3.5, P=0.09)\end{array}$ & Hiltermann et al. (2012) \\
\hline 31 Small cell lung cancers & $\begin{array}{l}\text { - Identification of chemosensitive and chemorefractory patients by CTCs } \\
\text { copy-number aberrations profile and observation of significant difference } \\
(P=0.0166) \text { in PFS between these two groups } \\
\text { - Difference in CTCs copy-number aberrations profile between initial and } \\
\text { acquired chemoresistance }\end{array}$ & Carter et al. (2017) \\
\hline
\end{tabular}

\section{Part 2. microRNAs}

\section{Molecular biogenesis and detection of} miRNAs miRNAs are endogenous small non-coding RNAs of 19-25 nucleotides in length that control eukaryotic gene expression post-transcriptionally through degradation or translation inhibition of specific mRNAs (He \& Hannon 2004). The first miRNA was discovered in Caenorhabditis elegans, over 20 years ago (Lee et al. 1993) and the following studies identified more than 300 miRNAs in animals and plants (Lagos-Quintana et al. 2001, Lau et al. 2001, Lai et al. 2003). There are now over 2500 mature human miRNAs annotated in the miRNA registry (http://mirbase.org). miRNA biogenesis is a multistep process composed by four phases: nuclear transcription, nuclear cropping, export to cytoplasm and cytoplasmic dicing (Lee et al. 2002, Kim 2004, 2005, http://erc.endocrinology-journals.org DOI: 10.1530/ERC-17-0091
๑ 2017 Society for Endocrinology Printed in Great Britain
Published by Bioscientifica Ltd. 
Kim et al. 2009). miRNA genes can be divided into intergenic, with independent transcription unit, and intragenic, located inside another gene in the introns or, in a minority, in the exons. Intergenic miRNA genes can be single-, bi- or poly-cistronic (Di Leva et al. 2014). In the nucleus, miRNA genes are transcribed by RNA polymerase II in primary miRNAs (pri-miRNAs); they have similar structure to mRNA such as 7-methyl guanylate (m7G) caps at 5'UTR and poly(A) tails at the 3'UTR (Lee et al. 2004). Some miRNAs, associated to Alu repeats and linked to cell cycle and growth regulation, are transcribed by RNA polymerase III (Borchert et al. 2006). The pri-miRNAs are usually several kilobases long and are characterized by a large stem-loop structure, with single-stranded RNA extensions at both ends. The pri-miRNA is then processed ('cropping') by the nuclear microprocessor complex, that includes RNase III endonuclease (Drosha) and the doublestranded RNA-binding protein DiGeorge syndrome critical region gene 8 (DGCR8), to form 60-100 nucleotide precursor miRNA (pre-miRNA) (Han et al. 2004, Yeom et al. 2006). Pre-miRNAs are then exported into the cytoplasm by the nuclear transport receptors exportin-5 (XPO-5) and its partner RanGTPase, which prevents nuclear degradation and facilitates translocation into the cytoplasm (Bohnsack et al. 2004). Finally, in the last processing step ('dicing'), pre-miRNA is cleaved by the cytoplasmic RNase III (Dicer) into $\sim 22$ nucleotides miRNA duplexes called miRNA/miRNA* (Kim 2005). Human dicer is associated with two proteins: TRBP (TAR RNA-binding protein) (Chendrimada et al. 2005) and the protein activator PACT (also known as PRKRA) (Lee et al. 2006). Both these proteins are responsible for recognizing the same binding domain of Dicer but are not essential for Dicer-mediated cleavage. At this point, the mature miRNA strand is incorporated into the RNA-induced silencing complex (RISC), whereas the other strand is usually degraded. miRNA guides RISC to target messenger RNA (mRNA). Perfect complementarity between miRNA and mRNA leads to cleavage and degradation of the latter, whereas imperfect complementarity results into suppression of the translation of the target mRNA (Tang 2005). Otherwise, mature miRNAs can be secreted by cells in biological fluids including plasma, serum, saliva and several other body fluids (Larrea et al. 2016). miRNAs can be released by passive secretion from cells that lost their integrity after tissue injury, cell apoptosis or necrosis (Laterza et al. 2009). An alternative hypothesis is that miRNAs are actively secreted from cells in microvesicles such as exosomes or shedding vesicles (Valadi et al. 2007) or conjugated to RNA-binding proteins (such as nucleophosmin 1 and argonaute 2) (Arroyo et al. 2011, Vickers et al. 2011). Circulating miRNAs might have great potential as minimally invasive biomarkers. In fact, miRNAs are more stable than mRNAs. Circulating miRNAs can be quantified by standard methods such as quantitative real-time PCR (qRT-PCR), hybridization technology (microarray) or next-generation sequencing (NGS) and in situ hybridization (ISH) (Uso et al. 2014). The starting material can be isolated from cell lines, blood and fresh or FFPE tissues (Xi et al. 2007). After extraction, the time between blood collection and processing should be short to prevent lysis and cellular contamination, which can be a major source of variability between samples (McDonald et al. 2011). Furthermore, the anti-coagulant used in plasma collection and heparin-coated tubes should be avoided because they influence downstream detection technologies (Al-Soud \& Radstrom 2001). The choice of the method to quantify circulating miRNAs depends on the required experimental design. Only wellknown miRNAs can be examined by qRT-PCR and microarray technology. qRT-PCR detects and quantifies miRNAs by fluorescence. miRNA microarrays is based on hybridization between target molecules (miRNAs) and complementary probes. qRT-PCR is more specific and sensitive than microarray platforms, but the latter allows large-scale studies. Moreover, new qRT-PCR arrays have been developed for large-scale miRNA profiling (Mohammadian et al. 2013). NGS is used to detect both novel and known miRNAs, with the limit that this technique is relatively expensive (Larrea et al. 2016). Finally, ISH technology may provide information regarding the exact localization of miRNAs within the tumor cell itself or within tumor stromal cells (Nuovo 2010), but has limited relevance as to circulating miRNAs are concerned. It should be borne in mind that the choice of the technique can deeply influence measurements; indeed, several studies show a lack of concordance between different methods when using the same sample source (Watson \& Witwer 2012). Therefore, the same method should always been used when performing clinical studies.

miRNAs as prognostic markers in human cancers Several studies have outlined an important role of miRNAs in prognosis and prediction of therapeutic outcome in several cancers. Both decreased and increased levels of various circulating miRNAs may be associated with poor outcome. Another potentiality is to predict 
Table 2 Role of circulating miRNAs as biomarkers of cancer.

\begin{tabular}{|c|c|c|c|c|}
\hline miRNA & De-regulation & Site & Role as biomarker & References \\
\hline $\operatorname{miR}-126 a$ & Up-regulated & Colon & Prognostic and potentially predictive & Hansen et al. (2013) \\
\hline miR-20a & Up-regulated & Colon & Diagnostic & Chen et al. (2015) \\
\hline miR-155 & Up-regulated & Breast & Prognostic and predictive & Roth et al. (2010), Sun et al. (2012) \\
\hline miR-195 & Up-regulated & Breast & Diagnostic & Heneghan et al. (2010) \\
\hline miR-29a, miR21 & Up-regulated & Breast & Diagnostic & Wu et al. (2011) \\
\hline miR-16 & Up-regulated & Breast & Diagnostic & Hu et al. (2012) \\
\hline \multicolumn{5}{|l|}{$\operatorname{miR}-25$} \\
\hline \multicolumn{5}{|l|}{ miR-222 } \\
\hline \multicolumn{5}{|l|}{ miR-324-3-p } \\
\hline let-7 & Up-regulated & Breast & Diagnostic and prognostic & Joosse et al. (2014) \\
\hline \multicolumn{5}{|l|}{ miR-202 } \\
\hline miR-18b & Up-regulated & Breast & Diagnostic and prognostic & Kleivi Sahlberg et al. (2015) \\
\hline \multicolumn{5}{|r|}{ 然 } \\
\hline \multicolumn{5}{|l|}{ miR-107 } \\
\hline \multicolumn{5}{|l|}{ miR-652 } \\
\hline miR-210 & Up-regulated & Breast & Predictive & Jung et al. (2012) \\
\hline $\operatorname{miR}-21$ & Up-regulated & Lung & Diagnostic, prognostic and predictive & Wei et al. (2011) \\
\hline miR-155, miR-197, miR-182 & Up-regulated & Lung & Diagnostic & Zheng et al. (2011) \\
\hline miR-125b & Up-regulated & Lung & Prognostic & Zhao et al. (2016) \\
\hline let-7a & Down-regulated & Prostate & Predictive of high grade tumor & Mihelich et al. (2015) \\
\hline \multicolumn{5}{|c|}{ - } \\
\hline \multicolumn{5}{|l|}{ miR-26b } \\
\hline \multicolumn{5}{|l|}{ miR-30c } \\
\hline \multicolumn{5}{|l|}{$\operatorname{miR} 93$} \\
\hline \multicolumn{5}{|l|}{ miR-100 } \\
\hline \multicolumn{5}{|l|}{ miR-103 } \\
\hline \multicolumn{5}{|l|}{ miR-106a } \\
\hline \multicolumn{5}{|l|}{ miR-107 } \\
\hline \multicolumn{5}{|l|}{ miR-130b } \\
\hline \multicolumn{5}{|l|}{ miR-146a } \\
\hline \multicolumn{5}{|l|}{$\operatorname{miR}-223$} \\
\hline \multicolumn{5}{|l|}{$\operatorname{miR}-451$} \\
\hline \multicolumn{5}{|l|}{$\operatorname{miR}-874$} \\
\hline $\operatorname{miR375}$ & Up-regulated & Prostate & Prognostic & Huang et al. (2015) \\
\hline $\operatorname{miR} 1290$ & & & & \\
\hline
\end{tabular}

tumor chemosensitivity. The most relevant studies are listed in Table 2.

miRNAs as prognostic markers in neuroendocrine tumors Several studies evaluated miRNA expression levels in NENs (Vicentini et al. 2014), but few examined their potential role as prognostic markers (Table 3). The prognostic role of specific miRNAs in lung NENs has been reported for the first time by Ranade and coworkers (Ranade et al. 2010), who examined the expression levels of 880 validated human mature miRNAs and 473 validated human pre-miRNAs in 31 small-cell lung cancer (SCLC) samples and found that miR-92a2* levels were inversely correlated with survival. They also showed that expression levels of miR-92a-2* ${ }^{*}$ miR-147 and miR-574-5p were significantly associated with chemoresistance. Following studies confirmed the association between miRNA expression levels and survival, supporting the prognostic role for miRNA signature in SCLC. Bi and coworkers (Bi et al. 2014) surveyed 924 known miRNAs in specimens deriving from 82 patients with SCLC, who were treated with surgical resection and adjuvant chemotherapy with platinum-based regimens. They discovered that lower miR-150 and miR-886-3p expression levels were associated with a poor OS and PFS. These findings retained statistical significance as independent predictors of survival after adjusting for age, gender and smoking status and confirmed the results of a previous study on the prognostic role of miR-886-3p levels in SCLC (Cao et al. 2013). In that study, miR.886-3p expression was found to be regulated by DNA promoter methylation and to potentially repress cell proliferation, migration and invasion. A prognostic role has also been indicated for miR-7, whose expression levels in 44 SCLC samples inversely associated with chemoresistance and OS (Liu et al. 2015). The authors also demonstrated that in vitro miR-7 
Table 3 Prognostic role of tissue miRNAs in NENs.

\begin{tabular}{|c|c|c|c|c|c|}
\hline miRNA & De-regulation & NEN histology & Number of cases & Prognostic role & References \\
\hline miR-92a2* & Up-regulated & $\mathrm{SCLC}$ & 31 & $\begin{array}{l}\text { Correlation with } \\
\text { chemoresistance and } \\
\text { reduced OS }\end{array}$ & Ranade et al. (2010) \\
\hline $\begin{array}{r}\operatorname{miR}-150 \text { and } \\
\text { miR-886-3p }\end{array}$ & Down-regulated & $\mathrm{SCLC}$ & 82 & $\begin{array}{l}\text { Correlation with reduced } \\
\text { OS and PFS }\end{array}$ & Bi et al. (2014) \\
\hline $\operatorname{miR}-886-3 p$ & Down-regulated & $\mathrm{SCLC}$ & 82 & $\begin{array}{l}\text { Correlation with reduced } \\
\text { OS and PFS }\end{array}$ & Cao et al. (2013) \\
\hline $\operatorname{miR}-7$ & Up-regulated & $\mathrm{SCLC}$ & 44 & $\begin{array}{l}\text { Correlation with } \\
\text { chemoresistance and } \\
\text { reduced OS }\end{array}$ & Liu et al. (2015) \\
\hline $\begin{array}{l}\text { miR-192, miR-200c, } \\
\text { miR-205 }\end{array}$ & Down-regulated & $\mathrm{SCLC}$ & 50 & $\begin{array}{l}\text { Correlation with } \\
\text { increased OS }\end{array}$ & Mancuso et al. (2016) \\
\hline $\operatorname{miR}-21$ & Up-regulated & Lung NENs & $\begin{array}{c}63 \text { (19 TC, } 6 \text { AC, } \\
19 \text { LCNEC, } \\
19 \text { SCLC) }\end{array}$ & $\begin{array}{l}\text { Correlation with presence } \\
\text { of lymph node } \\
\text { metastases in TC and AC }\end{array}$ & Lee et al. (2012) \\
\hline $\begin{array}{l}\text { let-7d, miR-19, } \\
\text { miR576-5p, } \\
\text { miR-340*, miR-1286 }\end{array}$ & Up-regulated & Lung NENs & $\begin{array}{c}12(3 \mathrm{TC}, 3 \mathrm{AC} \\
3 \mathrm{SCLC} \\
3 \mathrm{LCNEC})\end{array}$ & Correlation with OS & Mairinger et al. (2014) \\
\hline $\begin{array}{l}\operatorname{miR}-409-3 p, \operatorname{miR} \\
409-5 p, \operatorname{miR} 431-5 p\end{array}$ & Down-regulated & Lung NENs & $\begin{array}{c}37(22 \mathrm{TC} \\
15 \mathrm{AC})\end{array}$ & $\begin{array}{l}\text { Correlation with presence } \\
\text { of lymph node } \\
\text { metastases }\end{array}$ & Rapa et al. (2015) \\
\hline miR-21 & Up-regulated & Pancreatic NEN & 40 & $\begin{array}{l}\text { Correlation with Ki-67 } \\
\text { index and liver } \\
\text { metastases }\end{array}$ & Roldo et al. (2006) \\
\hline miR-642, miR-210 & Up-regulated & Pancreatic NEN & 37 & $\begin{array}{l}\text { Correlation with Ki-67 } \\
\text { index (miR-642) and with } \\
\text { metastatic spread } \\
\text { (miR-210) }\end{array}$ & Thorns et al. (2014) \\
\hline miR 196a & Up-regulated & Pancreatic NEN & 37 & $\begin{array}{l}\text { Correlation with advanced } \\
\text { stage, lymph node } \\
\text { metastases, higher } \\
\text { mitotic count, higher } \\
\text { Ki67 index, reduced OS } \\
\text { and DFS }\end{array}$ & Lee et al. (2015) \\
\hline miR-183, miR-375 & Up-regulated & MTC & 45 & $\begin{array}{l}\text { Correlation with lymph } \\
\text { node, residual disease } \\
\text { after surgery, distant } \\
\text { metastases and survival }\end{array}$ & Abraham et al. (2011) \\
\hline $\operatorname{miR}-224$ & Up-regulated & MTC & 40 & $\begin{array}{l}\text { Correlation with the } \\
\text { absence of node } \\
\text { metastases, lower stage } \\
\text { at diagnosis and } \\
\text { biochemical cure during } \\
\text { follow up }\end{array}$ & Mian et al. (2012) \\
\hline miR-21 & Up-regulated & MTC & 64 & $\begin{array}{l}\text { Correlation with basal } \\
\text { calcitonin levels, lymph } \\
\text { node metastases and } \\
\text { advanced disease at the } \\
\text { end of follow up }\end{array}$ & Pennelli et al. (2015) \\
\hline miR-1225-3p & Up-regulated & PC & 34 & $\begin{array}{l}\text { Correlation with } \\
\text { recurrence in sporadic PC }\end{array}$ & Tombol et al. (2010) \\
\hline $\operatorname{miR} 483-5 p$ & Up-regulated & PC & 24 & $\begin{array}{l}\text { Correlation with } \\
\text { metastatic spread and } \\
\text { shorter DFS }\end{array}$ & Meyer-Rochow et al. (2010) \\
\hline
\end{tabular}

AC, atypical carcinoids; DFS, disease-free survival; LCNEC, large cell neuroendocrine carcinomas; MTC, medullary thyroid carcinoma; OS, overall survival; PC, pheochromocytoma; PFS, progression-free survival; SCLC, small cell lung cancer; TC, typical carcinoids.

modulates chemoresistance by repressing MRP1/ABCC1, a mechanism known to be involved in chemoresistance in SCLC (Hsia et al. 2002, Kuo et al. 2003). An inverse correlation was found between OS and the expression levels of 3 miRNAs (miR-192, miR-200c and miR-205) in cytological samples from 50 SCLC patients (25 samples 
from primary tumors and 25 samples from lymph node metastases) (Mancuso et al. 2016). These miRNAs were selected because the respective target genes are frequently altered in SCLC. On the contrary, no association between miRNAs expression levels and survival or drug resistance was found by Lee and coworkers (Lee et al. 2011) who investigated the expression of a panel of seven miRNAs (miR-21, miR-29b, miR-34a/b/c, miR-155 and let-7a) in 31 SCLC tumor samples. The prognostic role of miRNAs in lung NENs has also been explored in another study (Lee et al. 2012), which evaluated the expression pattern of three miRNAs (miR-21, miR155 and miR let-7a), selected on the basis of their close correlation to tumor development and progression, in a series of 63 lung NENs, including 19 typical carcinoids (TC), 6 atypical carcinoids (AT), 19 large cell neuroendocrine carcinomas (LCNEC) and 19 SCLC. The results showed that miR-155 and miR-21 levels were significantly higher in high-grade neuroendocrine carcinomas (LCNECS and SCLC) as compared to TC and AC. In addition, miR-21 expression levels correlated with the presence of lymph node metastases in TC and AC, supporting the prognostic role of this miRNA in lung NENs. Mairinger and coworkers (Mairinger et al. 2014) screened 763 miRNAs known to be involved in pulmonary carcinogenesis in 12 lung NENs (3 TC, 3 AC, 3 SCLC and 3 LCNECS) and found that five miRNAs (let-7d, miR-19, miR576-5p, miR-340* and miR-1286) significantly associated with survival. Moreover, eight miRNAs (miR-22, miR-29a, miR-29b, miR-29c, miR-367*, miR-504, miR-513C and miR-1200) negatively correlated with tumor grade, whereas four miRNAs (miR-18a, miR$15 b^{*}$, miR-335* and miR-1201) positively correlated with tumor grade. On the contrary, no association between miRNA expression and disease-free survival was found by Deng and coworkers (Deng et al. 2014) who evaluated a panel of 1145 miRNAs in a series of 47 lung NENs (44 TC and $3 \mathrm{AC}$ ). Rapa and coworkers evaluated 56 cases of lung NENs (22 TC, 15 AC, 15 LCNECS and 4 SCLC) for the expression of 11 miRNAs (miR-15a, miR-22, miR-141, miR-497, miR-503, miR-129-5p, miR-185, miR-409-3p, miR-409-5p, miR-431-5p and miR-129*), selected on the basis of the results obtained in a previous pilot series. In agreement with the previous study by Mairinger and coworkers and by Lee and coworkers showing distinctive microRNA expression profiles in carcinoids as compared to high-grade neuroendocrine carcinoma, all but two miRNAs (miR-503 and miR-185) were significantly able to segregate different tumor histotypes. All but one miRNA (miR-431-5p) were found to be upregulated in the carcinoid group as compared to high-grade neuroendocrine carcinomas. Moreover, when evaluating the association between the 11 selected miRNAs and clinical and carcinoid pathological characteristics, four miRNAs (miR-129-5p, miR-129*, miR-22 and miR-141) were found downregulated in high-stage tumors, four miRNAs (miR-129-5p, miR-409-3p, miR-409-5p and miR431-5p) were found downregulated in cases with vascular invasion and three miRNAs (miR-409-3p, miR-409-5p and miR-431-5p) were found downregulated in tumors with lymph node metastases (Rapa et al. 2015).

Similarly, miRNA expression pattern in GEP NENs has been extensively investigated (Ruebel et al. 2010, Matthaei et al. 2012, Li et al. 2013a,b, 2015, Dossing et al. 2014, Miller et al. 2016), but few studies evaluated a possible prognostic role of miRNAs in GEP NEN. Roldo and coworkers (Roldo et al. 2006) evaluated the global miRNA expression in a series of 40 pNENs (28 nonfunctioning and 12 insulinomas) and found that miR-21 levels strongly associated with Ki67 labeling index and liver metastases. In addition, they have shown that the expression levels of programmed cell death 4 (PDCD4) gene were significantly downregulated in metastatic and highly proliferative tumors, where they inversely correlated with miR-21, in keeping with the hypothesis that PDCD4 is a target of miR-21. PDCD4, in turn, represents a tumor suppressor gene involved in invasion and metastasis (Jansen et al. 2004). Thorns and coworkers (Thorns et al. 2014) investigated the expression levels of 754 miRNAs in tissue samples of 37 patients with pNEN. They found that miR-642 and miR-210 correlated with Ki-67 labeling index and with metastatic spread, respectively, but could not provide information concerning survival. Lee and coworkers (Lee et al. 2015) evaluated the expression levels of eight miRNAs (miRNA-27b, 122, 142-5p, 196a, 223, 590-5p, 630 and 944) in 37 pNENs. High miR 196a levels were significantly associated with advanced stage, lymph node metastases, higher mitotic count, higher Ki67 index, reduced OS and DFS. The negative prognostic power of miR 196a in pNENs was conserved also when only the group of G2 NEN patients was considered. In addition, high miR-27b levels associated with decreased OS. Therefore, miRNA profiling may represent a useful prognostic tool in GEP NENs.

On the contrary, miRNA expression profiles in medullary thyroid carcinoma (MTC) have been evaluated in few studies (Nikiforova et al. 2008, Abraham et al. 2011, Mian et al. 2012, Hudson et al. 2013, Santarpia et al. 2013, Gundara et al. 2014, Pennelli et al. 2015, Lassalle et al. 2016), out of which only three evaluated the prognostic role of miRNAs in MTC. Abraham and coworkers

Published by Bioscientifica Ltd 
(Abraham et al. 2011) evaluated the expression of four miRNAs (miR-183, miR 375, miR 9 and miR 9*) selected on the basis of their reported significance in other cancers. They found that in 45 cases ( 26 sporadic and 19 hereditary MTC) miR-183 and miR-375 overexpression predicted lymph node metastases and was associated with residual disease after surgery, distant metastases and mortality. On the basis of these results, the authors proposed a possible use of these miRNAs in patients that do not show clinical nor radiological lymph node involvement before surgery in order to select those to be submitted to prophylactic lateral neck dissection or to guide a more stringent postoperative surveillance of the lateral neck compartment for evidence of recurrent disease. The authors corroborated their results with a functional study in the TT cell line, proving that miR-183 knockdown significantly decreased the number of viable cells, potentially via autophagy. Mian and coworkers (Mian et al. 2012) analyzed the expression of nine miRNAs (miR-21, miR-127, miR-154, miR-224, miR-323, miR-370, miR-9*, miR-183 and miR$375)$, selected on the basis of previous profiling studies, in 34 sporadic and in 6 hereditary MTC. They found that miR-224 upregulation correlated with the absence of node metastases, lower stage at diagnosis and biochemical cure during follow-up. At variance with the study by Abraham and coworkers (Abraham et al. 2011), Mian and coworkers (Mian et al. 2012) did not find a correlation between miR-183 or miR-375 levels and TNM stage or patients outcome. Subsequently, the same authors (Pennelli et al. 2015) studied the PDCD4/miR-21 pathway in 64 MTCs (56 sporadic and 8 hereditary). In line with the previous results obtained in GEP NEN (Roldo et al. 2006), they found that miR-21 levels inversely correlated with PDCD4 levels, confirming the latter as a target of miR21 . In addition, they found that miR-21 levels directly correlated with basal calcitonin levels, lymph node metastases and advanced disease at the end of follow-up. Along this line, PDCD4 levels correlated inversely with disease stage at diagnosis and directly with biochemically persistent disease at the end of follow-up. These studies pave the way for further validation studies, where the prognostic value of miRNA profiles should be investigated for clinical purposes.

Even fewer studies have reported microRNAs expression in pheochromocytomas (PC) and paragangliomas, so far (Patterson et al. 2012, de Cubas et al. 2013, Zong et al. 2015). These studies were mainly focused on the different miRNA expression profiles of hereditary tumor syndromes associated with PC and of benign vs. malignant PC.
This issue is extremely important as there are no reliable histologic or molecular markers that allow distinguishing benign from malignant PCs. Tombol and coworkers (Tombol et al. 2010) evaluated 34 PC cases including 9 sporadic benign, 5 sporadic recurrent tumors, 8 lesions in the settings of multiple endocrine neoplasia type 2, 6 associated with von Hippel Lindau disease, 5 with type 1 neurofibromatosis and 1 malignant PC. They observed that miR-1225-3p levels are higher in sporadic recurrent as compared to sporadic non-recurrent PC, providing a threshold value for miR-1225-3p also that identified a PC as recurrent with good sensitivity and specificity. MeyerRochow and coworkers (Meyer-Rochow et al. 2010) evaluated 12 benign and 12 malignant PCs and found a total of 18 miRNAs differentially expressed in benign as compared to malignant tumors. Three miRNAs (miR483-5p, miR-15a and miR 16) were selected for validation in a separate cohort of benign and malignant samples and confirmed to be diagnostic markers for malignant PC. In particular, high miR483-5p expression levels were found to be a negative prognostic marker as they were capable of predicting metastatic spread and reduced DFS.

In contrast with the evidence that tissue miRNAs may help in predicting NEN patient prognosis, few data are available concerning circulating miRNAs. The feasibility of measuring circulating miRNAs has been confirmed in studies performed in patients with small intestine NENs (Li et al. 2015) or pNENS (Li et al. 2013a). However, these studies do not provide information concerning patient prognosis. In addition, it has been reported that, as compared to healthy volunteers, patients with pNEN display very few different circulating microRNAs that are not the mostly deregulated in the tissue (Thorns et al. 2014). Moreover, a recent consensus on biomarkers for NENs (Oberg et al. 2015) concluded that circulating miRNA levels weakly associated with tissue miRNA levels that, in turn, have been found to vary widely. At present, clinical use of circulating miRNA is not recommended as the assessment needs further refinement, especially regarding normalization. Therefore, circulating miRNAs cannot be regarded as possible prognostic markers in NENs on the basis of available evidence.

\section{Conclusions}

The available literature data clearly show that tissue miRNA profiling may potentially represent a prognostic biomarker in NENs. However, the role of circulating miRNAs in these settings is far to be consolidated. 
Studies prospectively evaluating circulating miRNA in different NEN types (and stages) and their levels after the different available therapeutic approaches are still lacking. On the contrary, studies employing CTC count as a marker of NEN prognosis report very promising results that need to be validated in further clinical trials. Studies on selected validation cohorts with long-term clinical follow-up are necessary to further qualify CTC as biomarkers in NENs.

In conclusion, the field of research for reliable prognostic markers in NENs remains open, with the future perspective to identify specific characteristics or clinical algorithms that may help in planning the most appropriate clinical management for NEN patients.

\section{Declaration of interest}

M C Zatelli has received consultant fees from Novartis, Pfizer and Genzyme. The other authors declare that there is no conflict of interest that could be perceived as prejudicing the impartiality of this review.

\section{Funding}

This work was supported by grants from the Italian Ministry of Education, Research and University (FIRB RBAP11884M, RBAP1153LS); Associazione Italiana per la Ricerca sul Cancro (AIRC) in collaboration with 'Laboratorio in rete del Tecnopolo Tecnologie delle Terapie Avanzate' (LTTA) of the University of Ferrara. This review is part of the 'NIKE' project (Neuroendocrine tumors Innovation Knowledge and Education) led by Prof. Annamaria Colao, which aims at increasing the knowledge on NENs.

\section{Author contribution statement}

Maria Chiara Zatelli wrote the abstract, the Introduction, the part related to the role of circulating tumor cells as prognostic markers in NENs, the conclusions and revised the manuscript. Erika Maria Grossrubatscher wrote the part related to the role of miRNAs as prognostic markers in NENs. Elia Guadagno wrote the part related to the detection of CTCS as well as the part related to miRNAs and CTCs as prognostic markers in human cancers. Concetta Sciammarella wrote the part related to the biogenesis of miRNA and CTCs as well as the part related to the detection of miRNA. Antongiulio Faggiano proof-read the manuscript. Annamaria Colao supervised the project.

\section{Acknowledgements}

The authors would like to acknowledge all the collaborators of this project: Albertelli M (Genova), Amoroso V (Brescia), Arvat E (Torino), Badalamenti G (Palermo), Bajetta E (Monza), Baldelli R (Roma), Bianchi A (Roma), Botti G (Napoli), Buzzoni R (Milano), Campana D (Bologna), Carnaghi C (Milano), Cingarlini S (Verona), Circelli L (Napoli), Corcione F (Napoli), Davì M V (Verona), De Rosa G (Napoli), degli Uberti E (Ferrara), Delle Fave G (Roma), Del Basso De Caro M L (Napoli), Di Sarno A (Napoli), Faggiano A (Napoli), Falconi M (Milano), Fanciulli G (Sassari), Ferolla P (Perugia), Ferone D (Genova), Fiore F (Napoli), Gallo M (Torino), Gaudenzi G (Milano), Giordano C (Palermo), Giuffrida D (Catania), Guarnotta V (Palermo), Izzo F (Napoli), Lania A (Milano), Lastoria S (Napoli), Leo S (Lecce), Lo Calzo F (Napoli), Logoluso F (Bari), Malandrino P (Catania), Marchetti M (Padova), Marotta V (Napoli), Martini C (Padova), Mazzaferro V (Milano), Messina E
(Palermo), Milione M (Milano), Modica R (Napoli), Montesarchio V (Napoli), Muto P (Napoli), Nappi O (Napoli), Nazzari E (Genova), Panzuto F (Roma), Pia A (Torino), Piovesan A (Torino), Pizza G (Napoli), Pontecorvi A (Roma), Pusceddu S (Milano), Razzore P (Torino), Riccardi $F$ (Napoli), Rindi G (Roma), Rota F (Roma), Scarpa A (Verona), Spada F (Milano), Tafuto $S$ (Napoli), Versari A (Regg io Emilia), Vitale G (Milano), Volante M (Torino).

\section{References}

Abraham D, Jackson N, Gundara JS, Zhao J, Gill AJ, Delbridge L, Robinson BG \& Sidhu SB 2011 MicroRNA profiling of sporadic and hereditary medullary thyroid cancer identifies predictors of nodal metastasis, prognosis, and potential therapeutic targets. Clinical Cancer Research 17 4772-4781. (doi:10.1158/1078-0432.CCR-110242)

Alix-Panabieres C 2012 EPISPOT assay: detection of viable DTCs/CTCs in solid tumor patients. Recent Results in Cancer Research 195 69-76.

Alix-Panabieres C \& Pantel K 2013 Circulating tumor cells: liquid biopsy of cancer. Clinical Chemistry 59 110-118. (doi:10.1373/ clinchem.2012.194258)

Al-Soud WA \& Radstrom P 2001 Purification and characterization of PCR-inhibitory components in blood cells. Journal of Clinical Microbiology 39 485-493. (doi:10.1128/JCM.39.2.485-493.2001)

Arroyo JD, Chevillet JR, Kroh EM, Ruf IK, Pritchard CC, Gibson DF, Mitchell PS, Bennett CF, Pogosova-Agadjanyan EL, Stirewalt DL, et al. 2011 Argonaute 2 complexes carry a population of circulating microRNAs independent of vesicles in human plasma. PNAS 108 5003-5008. (doi:10.1073/pnas.1019055108)

Bethel K, Luttgen MS, Damani S, Kolatkar A, Lamy R, Sabouri-Ghomi M, Topol S, Topol EJ \& Kuhn P 2014 Fluid phase biopsy for detection and characterization of circulating endothelial cells in myocardial infarction. Physical Biology 11 016002. (doi:10.1088/14783975/11/1/016002)

Bi N, Cao J, Song Y, Shen J, Liu W, Fan J, He J, Shi Y, Zhang X, Lu $\mathrm{N}$, et al. 2014 A microRNA signature predicts survival in early stage small-cell lung cancer treated with surgery and adjuvant chemotherapy. PLOS ONE 9 e91388. (doi:10.1371/journal. pone.0091388)

Bidard FC, Fehm T, Ignatiadis M, Smerage JB, Alix-Panabieres C, Janni W, Messina C, Paoletti C, Muller V, Hayes DF, et al. 2013 Clinical application of circulating tumor cells in breast cancer: overview of the current interventional trials. Cancer and Metastasis Reviews 32 179-188. (doi:10.1007/s10555-012-9398-0)

Blom A, Bhatia S, Pietromonaco S, Koehler K, Iyer JG, Nagase K, Paulson K, Sabath DE \& Nghiem P 2014 Clinical utility of a circulating tumor cell assay in Merkel cell carcinoma. Journal of the American Academy of Dermatology 70 449-455. (doi:10.1016/j. jaad.2013.10.051)

Bohnsack MT, Czaplinski K \& Gorlich D 2004 Exportin 5 is a RanGTPdependent dsRNA-binding protein that mediates nuclear export of pre-miRNAs. RNA 10 185-191. (doi:10.1261/rna.5167604)

Borchert GM, Lanier W \& Davidson BL 2006 RNA polymerase III transcribes human microRNAs. Nature Structural and Molecular Biology 13 1097-1101. (doi:10.1038/nsmb1167)

Cao J, Song Y, Bi N, Shen J, Liu W, Fan J, Sun G, Tong T, He J, Shi $\mathrm{Y}$, et al. 2013 DNA methylation-mediated repression of miR-886-3p predicts poor outcome of human small cell lung cancer. Cancer Research 73 3326-3335. (doi:10.1158/0008-5472.CAN-12-3055)

Cao LL, Lu J, Lin JX, Zheng CH, Li P, Xie JW, Wang JB, Chen QY, Lin M, Tu RH, et al. 2016 A novel predictive model based on preoperative blood neutrophil-to-lymphocyte ratio for survival prognosis in patients with gastric neuroendocrine neoplasms. Oncotarget 7 42045-42058. (doi:10.18632/oncotarget.9805)

Capdevila J, Meeker A, Garcia-Carbonero R, Pietras K, Astudillo A, Casanovas O \& Scarpa A 2014 Molecular biology of neuroendocrine 
tumors: from pathways to biomarkers and targets. Cancer and Metastasis Reviews 33 345-351. (doi:10.1007/s10555-013-9468-y)

Carter L, Rothwell DG, Mesquita B, Smowton C, Leong HS, FernandezGutierrez F, Li Y, Burt DJ, Antonello J, Morrow CJ, et al. 2017 Molecular analysis of circulating tumor cells identifies distinct copynumber profiles in patients with chemosensitive and chemorefractory small-cell lung cancer. Nature Medicine 23 114-119. (doi:10.1038/nm.4239)

Chen XX \& Bai F 2015 Single-cell analyses of circulating tumor cells. Cancer Biology and Medicine 12 184-192. (doi:10.7497/j.issn.20953941.2015.0056)

Chen WY, Zhao XJ, Yu ZF, Hu FL, Liu YP, Cui BB, Dong XS \& Zhao YS 2015 The potential of plasma miRNAs for diagnosis and risk estimation of colorectal cancer. International Journal of Clinical and Experimental Pathology 8 7092-7101.

Chendrimada TP, Gregory RI, Kumaraswamy E, Norman J, Cooch N, Nishikura K \& Shiekhattar R 2005 TRBP recruits the Dicer complex to Ago2 for microRNA processing and gene silencing. Nature $\mathbf{4 3 6}$ 740-744. (doi:10.1038/nature03868)

Cohen SJ, Punt CJ, Iannotti N, Saidman BH, Sabbath KD, Gabrail NY, Picus J, Morse M, Mitchell E, Miller MC, et al. 2008 Relationship of circulating tumor cells to tumor response, progression-free survival, and overall survival in patients with metastatic colorectal cancer. Journal of Clinical Oncology 26 3213-3221. (doi:10.1200/ JCO.2007.15.8923)

Cohen SJ, Punt CJ, Iannotti N, Saidman BH, Sabbath KD, Gabrail NY, Picus J, Morse MA, Mitchell E, Miller MC, et al. 2009 Prognostic significance of circulating tumor cells in patients with metastatic colorectal cancer. Annals of Oncology 20 1223-1229. (doi:10.1093/ annonc/mdn786)

Cristofanilli M, Budd GT, Ellis MJ, Stopeck A, Matera J, Miller MC, Reuben JM, Doyle GV, Allard WJ, Terstappen LW, et al. 2004 Circulating tumor cells, disease progression, and survival in metastatic breast cancer. New England Journal of Medicine $\mathbf{3 5 1}$ 781-791. (doi:10.1056/NEJMoa040766)

Danila DC, Heller G, Gignac GA, Gonzalez-Espinoza R, Anand A, Tanaka E, Lilja H, Schwartz L, Larson S, Fleisher M, et al. 2007 Circulating tumor cell number and prognosis in progressive castration-resistant prostate cancer. Clinical Cancer Research 13 7053-7058. (doi:10.1158/1078-0432.CCR-07-1506)

de Bono JS, Scher HI, Montgomery RB, Parker C, Miller MC, Tissing H, Doyle GV, Terstappen LW, Pienta KJ \& Raghavan D 2008 Circulating tumor cells predict survival benefit from treatment in metastatic castration-resistant prostate cancer. Clinical Cancer Research 14 6302-6309. (doi:10.1158/1078-0432.CCR-08-0872)

de Cubas AA, Leandro-Garcia LJ, Schiavi F, Mancikova V, CominoMendez I, Inglada-Perez L, Perez-Martinez M, Ibarz N, XimenezEmbun P, Lopez-Jimenez E, et al. 2013 Integrative analysis of miRNA and mRNA expression profiles in pheochromocytoma and paraganglioma identifies genotype-specific markers and potentially regulated pathways. Endocrine-Related Cancer 20 477-493. (doi:10.1530/ERC-12-0183)

Deng B, Molina J, Aubry MC, Sun Z, Wang L, Eckloff BW, Vasmatzis G, You M, Wieben ED, Jen J, et al. 2014 Clinical biomarkers of pulmonary carcinoid tumors in never smokers via profiling miRNA and target mRNA. Cell and Bioscience 4 35. (doi:10.1186/2045-37014-35)

Di Leva G, Garofalo M \& Croce CM 2014 MicroRNAs in cancer. Annual Review of Pathology 9 287-314. (doi:10.1146/annurevpathol-012513-104715)

Dive C \& Brady G 2017 SnapShot: circulating tumor cells. Cell 168 742-742.e1. (doi:10.1016/j.cell.2017.01.026)

Dossing KB, Binderup T, Kaczkowski B, Jacobsen A, Rossing M, Winther O, Federspiel B, Knigge U, Kjaer A \& Friis-Hansen L 2014 Downregulation of miR-129-5p and the let-7 family in neuroendocrine tumors and metastases leads to up-regulation of their targets Egr1,
G3bp1, Hmga2 and Bach1. Genes 6 1-21. (doi:10.3390/ genes6010001)

Fabisiewicz A \& Grzybowska E 2017 CTC clusters in cancer progression and metastasis. Medical Oncology 3412.

Fidler IJ 1970 Metastasis: quantitative analysis of distribution and fate of tumor emboli labeled with 125 I-5-iodo-2'-deoxyuridine. Journal of the National Cancer Institute 45 773-782. (doi:10.1007/s12032-0160875-0)

Gaiser MR, Daily K, Hoffmann J, Brune M, Enk A \& Brownell I 2015 Evaluating blood levels of neuron specific enolase, chromogranin A, and circulating tumor cells as Merkel cell carcinoma biomarkers. Oncotarget 6 26472-26482. (doi:10.18632/oncotarget.4500)

Gao Y, Zhu Y, Zhang Z, Zhang C, Huang X \& Yuan Z 2016 Clinical significance of pancreatic circulating tumor cells using combined negative enrichment and immunostaining-fluorescence in situ hybridization. Journal of Experimental and Clinical Cancer Research $\mathbf{3 5}$ 66. (doi:10.1186/s13046-016-0340-0)

Gundara JS, Zhao JT, Gill AJ, Clifton-Bligh R, Robinson BG, Delbridge L \& Sidhu SB 2014 Nodal metastasis microRNA expression correlates with the primary tumour in MTC. ANZ Journal of Surgery $\mathbf{8 4}$ 235-239. (doi:10.1111/j.1445-2197.2012.06291.x)

Han J, Lee Y, Yeom KH, Kim YK, Jin H \& Kim VN 2004 The DroshaDGCR8 complex in primary microRNA processing. Genes and Development 18 3016-3027. (doi:10.1101/gad.1262504)

Hansen TF, Christensen R, Andersen RF, Sorensen FB, Johnsson A \& Jakobsen A 2013 MicroRNA-126 and epidermal growth factor-like domain 7-an angiogenic couple of importance in metastatic colorectal cancer. Results from the Nordic ACT trial. British Journal of Cancer 109 1243-1251. (doi:10.1093/annonc/mds138)

Harris L, Fritsche H, Mennel R, Norton L, Ravdin P, Taube S, Somerfield MR, Hayes DF, Bast RC Jr \& American Society of Clinical Oncology 2007 American Society of Clinical Oncology 2007 update of recommendations for the use of tumor markers in breast cancer. Journal of Clinical Oncology 25 5287-5312. (doi:10.1200/ JCO.2007.14.2364)

He L \& Hannon GJ 2004 MicroRNAs: small RNAs with a big role in gene regulation. Nature Reviews Genetics 5 522-531. (doi:10.1038/nrg1379)

Heneghan HM, Miller N, Kelly R, Newell J \& Kerin MJ 2010 Systemic miRNA-195 differentiates breast cancer from other malignancies and is a potential biomarker for detecting noninvasive and early stage disease. Oncologist 15 673-682. (doi:10.1634/ theoncologist.2010-0103)

Hiltermann TJ, Pore MM, van den Berg A, Timens W, Boezen HM, Liesker JJ, Schouwink JH, Wijnands WJ, Kerner GS, Kruyt FA, et al. 2012 Circulating tumor cells in small-cell lung cancer: a predictive and prognostic factor. Annals of Oncology 23 2937-2942. (doi:10.1093/annonc/mds138)

Hsia TC, Lin CC, Wang JJ, Ho ST \& Kao A 2002 Relationship between chemotherapy response of small cell lung cancer and P-glycoprotein or multidrug resistance-related protein expression. Lung 180 173-179. (doi:10.1007/s004080000091)

Hu Z, Dong J, Wang LE, Ma H, Liu J, Zhao Y, Tang J, Chen X, Dai J, Wei $Q$, et al. 2012 Serum microRNA profiling and breast cancer risk: the use of miR-484/191 as endogenous controls. Carcinogenesis 33 828-834. (doi:10.1093/carcin/bgs030)

Huang X, Yuan T, Liang M, Du M, Xia S, Dittmar R, Wang D, See W, Costello BA, Quevedo F, et al. 2015 Exosomal miR-1290 and miR-375 as prognostic markers in castration-resistant prostate cancer. European Urology 67 33-41. (doi:10.1016/j.eururo.2014.07.035)

Hudson J, Duncavage E, Tamburrino A, Salerno P, Xi L, Raffeld M, Moley J \& Chernock RD 2013 Overexpression of miR-10a and miR375 and downregulation of YAP1 in medullary thyroid carcinoma. Experimental and Molecular Pathology 95 62-67. (doi:10.1016/j. yexmp.2013.05.001)

Jansen AP, Camalier CE, Stark C \& Colburn NH 2004 Characterization of programmed cell death 4 in multiple human cancers reveals a 
novel enhancer of drug sensitivity. Molecular Cancer Therapeutics $\mathbf{3}$ 103-110.

Johnbeck CB, Knigge UP, Langer S, Jakobsen AL, Berthelsen AK, Federspiel B, Binderup T \& Kjaer A 2016 Prognostic value of 18F-FLT PET in patients with neuroendocrine neoplasms: a prospective headto-head comparison with 18F-FDG PET and Ki67 in 100 patients. Journal of Nuclear Medicine 57 1851-1857. (doi:10.2967/ jnumed.116.174714)

Joosse SA, Muller V, Steinbach B, Pantel K \& Schwarzenbach H 2014 Circulating cell-free cancer-testis MAGE-A RNA, BORIS RNA, let-7b and miR-202 in the blood of patients with breast cancer and benign breast diseases. British Journal of Cancer 111 909-917. (doi:10.1038/ bjc.2014.360)

Jung EJ, Santarpia L, Kim J, Esteva FJ, Moretti E, Buzdar AU, Di Leo A, Le XF, Bast RC, Jr., Park ST, et al. 2012 Plasma microRNA 210 levels correlate with sensitivity to trastuzumab and tumor presence in breast cancer patients. Cancer 118 2603-2614. (doi:10.1002/ cncr.26565)

Khan MS, Tsigani T, Rashid M, Rabouhans JS, Yu D, Luong TV, Caplin M \& Meyer T 2011 Circulating tumor cells and EpCAM expression in neuroendocrine tumors. Clinical Cancer Research 17 337-345. (doi:10.1158/1078-0432.CCR-10-1776)

Khan MS, Kirkwood A, Tsigani T, Garcia-Hernandez J, Hartley JA, Caplin ME \& Meyer T 2013 Circulating tumor cells as prognostic markers in neuroendocrine tumors. Journal of Clinical Oncology 31 365-372. (doi:10.1200/JCO.2012.44.2905)

Khan MS, Kirkwood AA, Tsigani T, Lowe H, Goldstein R, Hartley JA, Caplin ME \& Meyer T 2016 Early changes in circulating tumor cells are associated with response and survival following treatment of metastatic neuroendocrine neoplasms. Clinical Cancer Research 22 79-85. (doi:10.1158/1078-0432.CCR-15-1008)

Kim VN 2004 MicroRNA precursors in motion: exportin-5 mediates their nuclear export. Trends in Cell Biology 14 156-159. (doi:10.1016/j. tcb.2004.02.006)

Kim VN 2005 MicroRNA biogenesis: coordinated cropping and dicing. Nature Reviews Molecular Cell Biology 6 376-385. (doi:10.1038/ nrm1644)

Kim VN, Han J \& Siomi MC 2009 Biogenesis of small RNAs in animals. Nature Reviews Molecular Cell Biology 10 126-139. (doi:10.1038/ nrm2632)

Kleivi Sahlberg K, Bottai G, Naume B, Burwinkel B, Calin GA, Borresen-Dale AL \& Santarpia L 2015 A serum microRNA signature predicts tumor relapse and survival in triple-negative breast cancer patients. Clinical Cancer Research 21 1207-1214. (doi:10.1158/10780432.CCR-14-2011)

Krebs MG, Sloane R, Priest L, Lancashire L, Hou JM, Greystoke A, Ward TH, Ferraldeschi R, Hughes A, Clack G, et al. 2011 Evaluation and prognostic significance of circulating tumor cells in patients with non-small-cell lung cancer. Journal of Clinical Oncology 29 1556-1563. (doi:10.1200/JCO.2010.28.7045)

Kuo TH, Liu FY, Chuang CY, Wu HS, Wang JJ \& Kao A 2003 To predict response chemotherapy using technetium-99m tetrofosmin chest images in patients with untreated small cell lung cancer and compare with p-glycoprotein, multidrug resistance related protein-1, and lung resistance-related protein expression. Nuclear Medicine and Biology 30 627-632. (doi:10.1016/S0969-8051(03)00058-1)

Lagos-Quintana M, Rauhut R, Lendeckel W \& Tuschl T 2001 Identification of novel genes coding for small expressed RNAs. Science 294 853-858. (doi:10.1126/science.1064921)

Lai EC, Tomancak P, Williams RW \& Rubin GM 2003 Computational identification of Drosophila microRNA genes. Genome Biology 4 R42. (doi:10.1186/gb-2003-4-7-r42)

Langley RR \& Fidler IJ 2011 The seed and soil hypothesis revisited - the role of tumor-stroma interactions in metastasis to different organs. International Journal of Cancer 128 2527-2535. (doi:10.1002/ ijc.26031)
Larrea E, Sole C, Manterola L, Goicoechea I, Armesto M, Arestin M, Caffarel MM, Araujo AM, Araiz M, Fernandez-Mercado M, et al. 2016 New concepts in cancer biomarkers: circulating miRNAs in liquid biopsies. International Journal of Molecular Sciences 17 E627. (doi:10.3390/ijms17050627)

Lassalle S, Zangari J, Popa A, Ilie M, Hofman V, Long E, Patey M, Tissier F, Belleannee G, Trouette H, et al. 2016 MicroRNA-375/SEC23A as biomarkers of the in vitro efficacy of vandetanib. Oncotarget 7 30461-30478. (doi:10.18632/oncotarget.8458)

Laterza OF, Lim L, Garrett-Engele PW, Vlasakova K, Muniappa N, Tanaka WK, Johnson JM, Sina JF, Fare TL, Sistare FD, et al. 2009 Plasma MicroRNAs as sensitive and specific biomarkers of tissue injury. Clinical Chemistry 55 1977-1983. (doi:10.1373/ clinchem.2009.131797)

Lau NC, Lim LP, Weinstein EG \& Bartel DP 2001 An abundant class of tiny RNAs with probable regulatory roles in Caenorhabditis elegans. Science 294 858-862. (doi:10.1126/science.1065062)

Lee RC, Feinbaum RL \& Ambros V 1993 The C. elegans heterochronic gene lin-4 encodes small RNAs with antisense complementarity to lin-14. Cell 75 886-883.

Lee Y, Jeon K, Lee JT, Kim S \& Kim VN 2002 MicroRNA maturation: stepwise processing and subcellular localization. EMBO Journal $\mathbf{2 1}$ 843-854.

Lee Y, Kim M, Han J, Yeom KH, Lee S, Baek SH \& Kim VN 2004 MicroRNA genes are transcribed by RNA polymerase II. EMBO Journal 23 522-532. (doi:10.1038/sj.emboj.7600514)

Lee Y, Hur I, Park SY, Kim YK, Suh MR \& Kim VN 2006 The role of PACT in the RNA silencing pathway. EMBO Journal 25 129-125. (doi:10.1038/sj.emboj.7600902)

Lee JH, Voortman J, Dingemans AM, Voeller DM, Pham T, Wang Y \& Giaccone G 2011 MicroRNA expression and clinical outcome of small cell lung cancer. PLoS ONE 6 e21300. (doi:10.1371/journal. pone.0021300)

Lee HW, Lee EH, Ha SY, Lee CH, Chang HK, Chang S, Kwon KY, Hwang IS, Roh MS \& Seo JW 2012 Altered expression of microRNA miR-21, miR-155, and let-7a and their roles in pulmonary neuroendocrine tumors. Pathology International 62 583-591. (doi:10.1111/ j.1440-1827.2012.02845.x)

Lee YS, Kim H, Kim HW, Lee JC, Paik KH, Kang J, Kim J, Yoon YS, Han HS, Sohn I, et al. 2015 High expression of microRNA-196a indicates poor prognosis in resected pancreatic neuroendocrine tumor. Medicine 94 e2224. (doi:10.1097/MD.0000000000002224)

Li A, Yu J, Kim H, Wolfgang CL, Canto MI, Hruban RH \& Goggins M 2013a MicroRNA array analysis finds elevated serum miR-1290 accurately distinguishes patients with low-stage pancreatic cancer from healthy and disease controls. Clinical Cancer Research 19 4663-4670. (doi:10.1158/1078-0432.CCR-12-3092)

Li SC, Essaghir A, Martijn C, Lloyd RV, Demoulin JB, Oberg K \& Giandomenico V 2013b Global microRNA profiling of welldifferentiated small intestinal neuroendocrine tumors. Modern Pathology 26 4051-4060. (doi:10.1038/modpathol.2012.216)

Li SC, Khan M, Caplin M, Meyer T, Oberg K \& Giandomenico V 2015 Somatostatin analogs treated small intestinal neuroendocrine tumor patients circulating microRNAs. PLOS ONE 10 e0125553. (doi:10.1371/journal.pone.0125553)

Liu H, Wu X, Huang J, Peng J \& Guo L 2015 miR-7 modulates chemoresistance of small cell lung cancer by repressing MRP1/ ABCC1. International Journal of Experimental Pathology 96 3600-3610. (doi:10.1111/iep.12131)

Mairinger FD, Ting S, Werner R, Walter RF, Hager T, Vollbrecht C, Christoph D, Worm K, Mairinger T, Sheu-Grabellus SY, et al. 2014 Different micro-RNA expression profiles distinguish subtypes of neuroendocrine tumors of the lung: results of a profiling study. Modern Pathology 27 685-696. (doi:10.1038/modpathol.2014.74)

Mancuso G, Bovio E, Rena O, Rrapaj E, Mercalli F, Veggiani C, Paganotti A, Andorno S \& Boldorini R 2016 Prognostic impact of a

Published by Bioscientifica Ltd. 
3-MicroRNA signature in cytological samples of small cell lung cancer. Cancer Cytopathology 124 240-247. (doi:10.1002/cncy.21729)

Mathew A, Brufsky AM \& Davidson NE 2015 Can circulating tumor cells predict resistance in metastatic breast cancer? Clinical Cancer Research 21 1632-1640. (doi:10.1158/1078-0432.CCR-14-2967)

Matthaei H, Wylie D, Lloyd MB, Dal Molin M, Kemppainen J, Mayo SC, Wolfgang CL, Schulick RD, Langfield L, Andruss BF, et al. 2012 miRNA biomarkers in cyst fluid augment the diagnosis and management of pancreatic cysts. Clinical Cancer Research 18 621-629. (doi:10.1158/1078-0432.CCR-12-0035)

McDonald JS, Milosevic D, Reddi HV, Grebe SK \& Algeciras-Schimnich A 2011 Analysis of circulating microRNA: preanalytical and analytical challenges. Clinical Chemistry 57 2421-2423. (doi:10.1373/ clinchem.2010.157198)

Meyer-Rochow GY, Jackson NE, Conaglen JV, Whittle DE, Kunnimalaiyaan M, Chen H, Westin G, Sandgren J, Stalberg P, Khanafshar E, et al. 2010 MicroRNA profiling of benign and malignant pheochromocytomas identifies novel diagnostic and therapeutic targets. Endocrine-Related Cancer 17 4713-4724. (doi:10.1677/ERC-10-0142)

Mian C, Pennelli G, Fassan M, Balistreri M, Barollo S, Cavedon E, Galuppini F, Pizzi M, Vianello F, Pelizzo MR, et al. 2012 MicroRNA profiles in familial and sporadic medullary thyroid carcinoma: preliminary relationships with RET status and outcome. Thyroid 22 833-840. (doi:10.1089/thy.2012.0045)

Mihelich BL, Maranville JC, Nolley R, Peehl DM \& Nonn L 2015 Elevated serum microRNA levels associate with absence of highgrade prostate cancer in a retrospective cohort. PLoS One $\mathbf{1 0}$ e0124245. (doi:10.1371/journal.pone.0124245)

Miller HC, Frampton AE, Malczewska A, Ottaviani S, Stronach EA, Flora R, Kaemmerer D, Schwach G, Pfragner R, Faiz O, et al. 2016 MicroRNAs associated with small bowel neuroendocrine tumours and their metastases. Endocrine-Related Cancer 23 835-846. (doi:10.1530/ERC-16-0044)

Mohammadian A, Mowla SJ, Elahi E, Tavallaei M, Nourani MR \& Liang Y 2013 Normalization of miRNA qPCR high-throughput data: a comparison of methods. Biotechnology Letters 35 890-896. (doi:10.1007/s10529-013-1150-5)

Nikiforova MN, Tseng GC, Steward D, Diorio D \& Nikiforov YE 2008 MicroRNA expression profiling of thyroid tumors: biological significance and diagnostic utility. Journal of Clinical Endocrinology and Metabolism 93 711-726. (doi:10.1210/jc.2007-2696)

Nuovo GJ 2010 In situ detection of microRNAs in paraffin embedded, formalin fixed tissues and the co-localization of their putative targets. Methods 52 843-851. (doi:10.1016/j.ymeth.2010.08.009)

Oberg K, Modlin IM, De Herder W, Pavel M, Klimstra D, Frilling A, Metz DC, Heaney A, Kwekkeboom D, Strosberg J, et al. 2015 Consensus on biomarkers for neuroendocrine tumour disease. Lancet Oncology 16 e1600-e1608. (doi:10.1016/S1470-2045(15)00186-2)

Olmos D, Arkenau HT, Ang JE, Ledaki I, Attard G, Carden CP, Reid AH, $\mathrm{A}^{\prime}$ Hern R, Fong PC, Oomen NB, et al. 2009 Circulating tumour cell (CTC) counts as intermediate end points in castration-resistant prostate cancer (CRPC): a single-centre experience. Annals of Oncology 20 307-315. (doi:10.1093/annonc/mdn544)

Pachmann U 2008 An increase in cell number at completion of therapy may develop as an indicator of early relapse: quantification of circulating epithelial tumor cells (CETC) for monitoring of adjuvant therapy in breast cancer. Journal of Cancer Research and Clinical Oncology 134 59-65. (doi:10.1007/s00432-007-0248-3)

Parkinson DR, Dracopoli N, Petty BG, Compton C, Cristofanilli M, Deisseroth A, Hayes DF, Kapke G, Kumar P, Lee J, et al. 2012 Considerations in the development of circulating tumor cell technology for clinical use. Journal of Translational Medicine 10138. (doi:10.1186/1479-5876-10-138)

Patterson E, Webb R, Weisbrod A, Bian B, He M, Zhang L, Holloway AK, Krishna R, Nilubol N, Pacak K, et al. 2012 The microRNA expression changes associated with malignancy and SDHB mutation in pheochromocytoma. Endocrine-Related Cancer 19 435-446. (doi:10.1530/ERC-11-0306)

Pennelli G, Galuppini F, Barollo S, Cavedon E, Bertazza L, Fassan M, Guzzardo V, Pelizzo MR, Rugge M \& Mian C 2015 The PDCD4/miR21 pathway in medullary thyroid carcinoma. Human Pathology $\mathbf{4 6}$ 27-33. (doi:10.1016/j.humpath.2014.09.006)

Ranade AR, Cherba D, Sridhar S, Richardson P, Webb C, Paripati A, Bowles B \& Weiss GJ 2010 MicroRNA 92a-2*: a biomarker predictive for chemoresistance and prognostic for survival in patients with small cell lung cancer. Journal of Thoracic Oncology 5 157-166. (doi:10.1097/JTO.0b013e3181dea6be)

Rapa I, Votta A, Felice B, Righi L, Giorcelli J, Scarpa A, Speel E-J M, Scagliotti GV, Papotti M \& Volante M 2015 Identification of microRNAs differentially expressed in lung carcinoid subtypes and progression. Neuroendocrinology $10150-57$. (doi:10.1159/000381454)

Roldo C, Missiaglia E, Hagan JP, Falconi M, Capelli P, Bersani S, Calin GA, Volinia S, Liu CG, Scarpa A, et al. 2006 MicroRNA expression abnormalities in pancreatic endocrine and acinar tumors are associated with distinctive pathologic features and clinical behavior. Journal of Clinical Oncology 24 1273-1278. (doi:10.1200/ JCO.2005.04.7522)

Roth C, Rack B, Muller V, Janni W, Pantel K \& Schwarzenbach H 2010 Circulating microRNAs as blood-based markers for patients with primary and metastatic breast cancer. Breast Cancer Research 12 R90. (doi:10.1186/bcr2766)

Ruebel K, Leontovich AA, Stilling GA, Zhang S, Righi A, Jin L \& Lloyd RV 2010 MicroRNA expression in ileal carcinoid tumors: downregulation of microRNA-133a with tumor progression. Modern Pathology 23 246-255. (doi:10.1038/modpathol.2009.161)

Ruzzenente A, Bagante F, Bertuzzo F, Aldrighetti L, Ercolani G, Giuliante F, Ferrero A, Torzilli G, Grazi GL, Ratti F, et al. 2016 A novel nomogram to predict the prognosis of patients undergoing liver resection for neuroendocrine liver metastasis: an analysis of the Italian neuroendocrine liver metastasis database. Journal of Gastrointestinal Surgery 21 4677-4684. (doi:10.1007/s11605-0163228-6)

Santarpia L, Calin GA, Adam L, Ye L, Fusco A, Giunti S, Thaller C, Paladini L, Zhang X, Jimenez C, et al. 2013 A miRNA signature associated with human metastatic medullary thyroid carcinoma. Endocrine-Related Cancer 20 367-375. (doi:10.1530/ERC-13-0357)

Saucedo-Zeni N, Mewes S, Niestroj R, Gasiorowski L, Murawa D, Nowaczyk P, Tomasi T, Weber E, Dworacki G, Morgenthaler $\mathrm{NG}$, et al. 2012 A novel method for the in vivo isolation of circulating tumor cells from peripheral blood of cancer patients using a functionalized and structured medical wire. International Journal of Oncology 41 41-48. (doi:10.3892/ijo.2012.1557)

Sieuwerts AM, Kraan J, Bolt-de Vries J, van der Spoel P, Mostert B, Martens JW, Gratama JW, Sleijfer S \& Foekens JA 2009 Molecular characterization of circulating tumor cells in large quantities of contaminating leukocytes by a multiplex real-time PCR. Breast Cancer Research and Treatment 118 809-823. (doi:10.1007/s10549008-0290-0)

Smerage JB, Barlow WE, Hortobagyi GN, Winer EP, Leyland-Jones B, Srkalovic G, Tejwani S, Schott AF, O'Rourke MA, Lew DL, et al. 2014 Circulating tumor cells and response to chemotherapy in metastatic breast cancer: SWOG S0500. Journal of Clinical Oncology 32 1241-1250. (doi:10.1200/JCO.2014.56.2561)

Tang G 2005 siRNA and miRNA: an insight into RISCs. Trends in Biochemical Sciences 30 455-468. (doi:10.1016/j.tibs.2004.12.007)

Thiery JP 2002 Epithelial-mesenchymal transitions in tumour progression. Nature Reviews Cancer 2 3483-3489. (doi:10.1038/ nrc822)

Thorns C, Schurmann C, Gebauer N, Wallaschofski H, Kumpers C, Bernard V, Feller AC, Keck T, Habermann JK, Begum N, et al. 2014

Published by Bioscientifica Ltd. 
Global microRNA profiling of pancreatic neuroendocrine neoplasias. Anticancer Research 34 106-114.

Tombol Z, Eder K, Kovacs A, Szabo PM, Kulka J, Liko I, Zalatnai A, Racz G, Toth M, Patocs A, et al. 2010 MicroRNA expression profiling in benign (sporadic and hereditary) and recurring adrenal pheochromocytomas. Modern Pathology 23 442-454. (doi:10.1038/ modpathol.2010.164)

Ushiku H, Yamashita K, Kawamata H, Waraya M, Katoh H, Yokoi K, Tanaka T, Ishii S, Nishizawa N, Kikuchi M, et al. 2016 Homeoboxonly protein expression is a critical prognostic indicator of pancreatic neuroendocrine tumor and is regulated by promoter DNA hypermethylation. Pancreas 45 1255-1262. (doi:10.1097/ MPA.0000000000000646)

Uso M, Jantus-Lewintre E, Sirera R, Bremnes RM \& Camps C 2014 miRNA detection methods and clinical implications in lung cancer. Future Oncology 10 2249-2254.

Valadi H, Ekstrom K, Bossios A, Sjostrand M, Lee JJ \& Lotvall JO 2007 Exosome-mediated transfer of mRNAs and microRNAs is a novel mechanism of genetic exchange between cells. Nature Cell Biology 9 1583-1595. (doi:10.1038/ncb1596)

Verbeek WH, Korse CM \& Tesselaar ME 2016 GEP-NETs UPDATE: secreting gastro-enteropancreatic neuroendocrine tumours and biomarkers. European Journal of Endocrinology 174 R2279-R2292.

Vicentini C, Fassan M, D’Angelo E, Corbo V, Silvestris N, Nuovo GJ \& Scarpa A 2014 Clinical application of microRNA testing in neuroendocrine tumors of the gastrointestinal tract. Molecules 19 654-659. (doi:10.3390/molecules19022458)

Vickers KC, Palmisano BT, Shoucri BM, Shamburek RD \& Remaley AT 2011 MicroRNAs are transported in plasma and delivered to recipient cells by high-density lipoproteins. Nature Cell Biology $\mathbf{1 3}$ 1-7. (doi:10.1038/ncb0111-1)

Villani V, Mahadevan KK, Ligorio M, Fernandez-Del Castillo C, Ting DT, Sabbatino F, Zhang I, Vangel M, Ferrone S, Warshaw AL, et al. 2016 Phosphorylated histone H3 (PHH3) is a superior proliferation marker for prognosis of pancreatic neuroendocrine tumors. Annals of Surgical Oncology 23 (Supplement 5) 2458-2468. (doi:10.1245/s10434-0165171-x)

Wang L, Balasubramanian P, Chen AP, Kummar S, Evrard YA \& Kinders RJ 2016 Promise and limits of the CellSearch platform for evaluating pharmacodynamics in circulating tumor cells. Seminars in Oncology 43 609-617. (doi:10.1053/j.seminoncol.2016.06.004)
Wang H, Stoecklein NH, Lin PP \& Gires O 2017 Circulating and disseminated tumor cells: diagnostic tools and therapeutic targets in motion. Oncotarget 8 423-433. (doi:10.18632/oncotarget.12242)

Watson AK \& Witwer KW 2012 Do platform-specific factors explain microRNA profiling disparities? Clinical Chemistry 58 1884-1912; author reply 464-475. (doi:10.1373/clinchem.2011.175281)

Wei J, Gao W, Zhu CJ, Liu YQ, Mei Z, Cheng T \& Shu YQ 2011 Identification of plasma microRNA-21 as a biomarker for early detection and chemosensitivity of non-small cell lung cancer. Chinese Journal of Cancer 30 407-414.

Wu Q, Lu Z, Li H, Lu J, Guo L \& Ge Q 2011 Next-generation sequencing of microRNAs for breast cancer detection. Journal of Biomedicine and Biotechnology 2011 597145. (doi:10.1155/2011/597145)

Xi Y, Nakajima G, Gavin E, Morris CG, Kudo K, Hayashi K \& Ju J 2007 Systematic analysis of microRNA expression of RNA extracted from fresh frozen and formalin-fixed paraffin-embedded samples. RNA $\mathbf{1 3}$ 472-474. (doi:10.1261/rna.642907)

Yanagita M, Redig AJ, Paweletz CP, Dahlberg SE, O'Connell A, Feeney N, Taibi M, Boucher D, Oxnard GR, Johnson BE, et al. 2016 A prospective evaluation of circulating tumor cells and cell-free DNA in EGFR mutant non-small cell lung cancer patients treated with erlotinib on a phase II trial. Clinical Cancer Research 22 474-475. (doi:10.1158/1078-0432.CCR-16-0909)

Yeom KH, Lee Y, Han J, Suh MR \& Kim VN 2006 Characterization of DGCR8/Pasha, the essential cofactor for Drosha in primary miRNA processing. Nucleic Acids Research 34 1668-1674. (doi:10.1093/nar/ gkl110)

Zhang L, Riethdorf S, Wu G, Wang T, Yang K, Peng G, Liu J \& Pantel K 2012 Meta-analysis of the prognostic value of circulating tumor cells in breast cancer. Clinical Cancer Research 18 6010-6020. (doi:10.1158/1078-0432.CCR-12-1587)

Zhao C, Lu F, Chen H, Zhao F, Zhu Z, Zhao X \& Chen H 2016 Clinical significance of circulating miRNA detection in lung cancer. Medical Oncology 3341.

Zheng D, Haddadin S, Wang Y, Gu LQ, Perry MC, Freter CE \& Wang MX 2011 Plasma microRNAs as novel biomarkers for early detection of lung cancer. International Journal of Clinical and Experimental Pathology 4 575-586.

Zong L, Meng L \& Shi R 2015 Role of miR-101 in pheochromocytoma patients with SDHD mutation. International Journal of Clinical and Experimental Pathology 8 4622-4629.

Received in final form 20 March 2017

Accepted 7 April 2017

Accepted Preprint published online 7 April 2017
() 2017 Society for Endocrinology Printed in Great Britain
Published by Bioscientifica Ltd 